\title{
蒸発効率を指標とした壁面緑化の蒸発特性
}

\section{Evaluation of Transpiration Properties of Wall Greening Using Evaporation Efficiency Rate as an Index}

\author{
鈴木 弘孝* 三坂 育正 ${ }^{* *}$ 田代 順孝*** \\ Hirotaka SUZUKI Ikusei MISAKA Yoritaka TASHIRO
}

\begin{abstract}
In this study, the evaporation efficiency, which is a heat balance parameter necessary for numerical simulation of greening effects, was derived in order to quantitatively evaluate the effects of wall greening panels on improving the thermal environment. The efficiency was determined by monitoring the amount of evapotranspiration from wall greening panels on which either Hedera helix or Euonymus fortunei was planted, calculating the sensible heat-flux from S A T measurements, and determining the convective heat transfer rate, material transfer rate and the difference between the measured and calculated amounts of evaportranspiration. The results showed that: 1) both the convection heat transfer rate and material transfer rate were highly correlated to wind speed, and the derived equations for calculating the rates were functions of wind speed, 2) the mean evaporation efficiency for the monitoring period was 0.25 for Hedera helix and 0.26 for Euonymus fortunei, and 3) the amounts of evaporation from the wall greening panels tested were 4 to $5 \mathrm{~mm}$ for both plant species and showed correlations to daily cumulative irradiation.
\end{abstract}

Keywords: wall greening, heat-island, thermal environment, heat balance, evaporation efficiency rate キーワード：壁面緑化，ヒートアイランド，温熱環境，熱収支，蒸発効率

\section{1. 研究の背景と目的}

都市域がその周辺地域よりも高温となる，いわゆるヒートアイ ランド現象を緩和するための主要な対策として, 地表面被覆の改 善が挙げられる。特に, 不透水化した都市においては, 緑地面積 を増大することが有効であるとされているが，高度に密集化した 都市市街地に大規模な緑地を面的に確保することは難しく, 建築 物の緑化等により緑地面積を拡大することが必要とされている ${ }^{1)} 。$ 建築物の緑化に関して, 屋上緑化の技術についてはすでに多く の技術開発や普及が進んでいる段階にあり，そのヒートアイラン ド緩和効果に関しても多くの研究例が見られ ${ }^{22,3)}$, 植物の蒸発散 による表面温度の低下や顕熱の低減といった効果が実験や実測に よって明らかにされている。しかしながら, 地上部の気温低減に おいて効果が期待されている壁面緑化に関しては, 技術面におい ても開発途上の段階であるが，その温熱環境改善効果について， 日射遮蔽や放射環境に関する評価 ${ }^{4,5)}$ ( 特性や熱収支特性などの定量的な評価についての研究蓄積は十分 とは言えない。今後壁面緑化システムの開発と普及を促進する上 では, 緑化対策による温熱環境改善効果を定量的に評価できるこ とが必要であると考えられる。

壁面緑化による主要な温熱環境改善効果として, 植物の蒸散等 により気化熱を潜熱として消費することに伴う顕熱の抑制効果を 指摘できる。成田ら ${ }^{6), 7)}$ は, 新宿御苑の芝生地を対象として放射 収支と渦相関法による顕熱フラックスの測定から熱収支パラメー 夕として蒸発効率を算出しているが, 渦相関法の場合, 風上側に 十分なフェッチが必要であり, 現状の壁面緑化の形態や施工状況 を考慮すると, 実験計測の際に十分なフェッチを確保することは 困難と考えられ，より簡易な評価手法を検討する必要がある。

一方, 壁面緑化に使用されている植物を対象とした蒸散効果の 評価では, 野島ら ${ }^{8)}$ がスーパーポロメーターを用いて蒸散速度の 計測による蒸散量推定の試みがあるが，この推定では実測值との 間の整合についての検証が十分になされてはいない。また，萩島
ら ${ }^{9), 10)}$ は, ブルーパシフィックを使用したユニット型の壁面緑化 システムを対象として S A T 計を用いた表面熱収支の観測を行い, 蒸発特性を明らかにしたが，使用植物は針葉樹に限定され，植物 からの蒸散量についての検証も十分とは言えない。したがって， 壁面緑化について蒸発散量の実測デー夕の蓄積は不十分であり, 壁面緑化による温熱環境改善効果についての解明と定量的な評価 を行う上で, 実測デー夕に基づく蒸発散の熱収支特性を明らかに していく必要がある。蒸発散による熱収支については，成田らが 既報 ${ }^{6), 11,12)}$ にて算出した方法を参考として蒸発効率を指標とする ことにより, 壁面緑化による温熱環境改善効果についてシミュレー ション評価等を行う場合のパラメータとしての活用が期待でき, 実証性の高い定量評価が可能になると考えられる。

そこで, 本研究は, 壁面緑化による温熱環境改善効果を定量的 に捕捉することを目的として, 壁面緑化に使用されている緑化パ ネルを試験体として，重量法による蒸発散の実験・計測を行うと ともに, S A T 計法 ${ }^{13)}$ により対流熱伝達率と物質伝達率を求め, 壁面緑化の蒸発散特性を示す指標として蒸発効率の算出を試みた。

\section{2. 研究の方法}

\section{(1) 実験装置}

独立行政法人建築研究所 (茨城県つくば市)の実験棟 1 階屋上部 の南に面した壁に, 緑化パネル試験体を 2 基設置した。試験体は 1 ユニットが縦 $30 \mathrm{~cm} \times$ 横 $30 \mathrm{~cm} \times$ 厚さ $8 \mathrm{~cm}$ のピートモスを基盤 材とした緑化パネルを縦, 横各 6 個の計 36 個のユニットで構成 し, 縦 $1.8 \mathrm{~m} \times$ 横 $1.8 \mathrm{~m}$ の試験体を地表から約 $1 \mathrm{~m}$ の地点に設置 した。試験体の使用植物は, ヘデラヘリックス(Hedera herix) と アメリカツルマサキ(Euonymus fortunei) で，埼玉県大里郡寄居 町の苗圃内温室おいて同一の親木から採取して栽培された 2 年生 のさし穂を使用した。さし穂は夕テ $40 \mathrm{~mm}, \exists コ 40 \mathrm{~mm}$, 深さ $50 \mathrm{~mm}$ の四角錐のセルトレイ中にピートモスとバーク堆肥, 赤 土を 1:1:8 の比率で混合した培土で栽培されたもので，2005 年 5

*(独)建築研究所住宅・都市研究グループ **(株)竹中工務店技術研究所先端研究開発部 ${ }^{* * *}$ 千葉大学園芸学部緑地・環境学科 


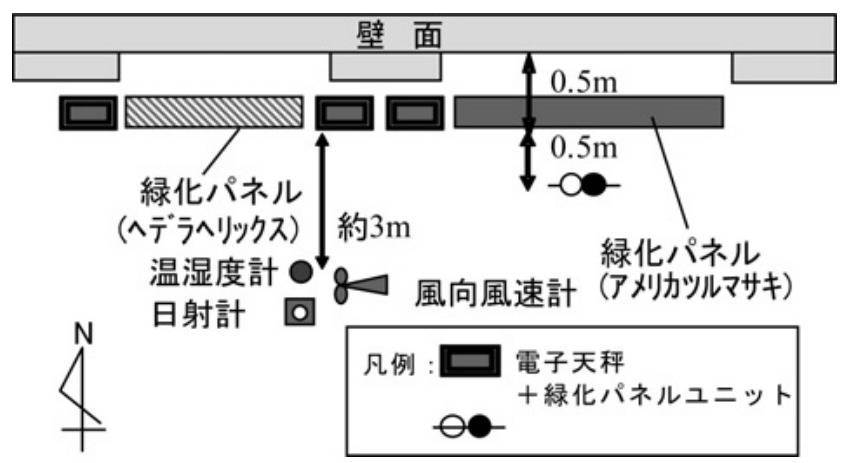

図-1 緑化試験体および計測機器設置状況

表 -1 測定項目亡計測機器

\begin{tabular}{|c|c|c|c|}
\hline 訃測項目 & 訃測機器名 & 型番 & 数量 \\
\hline 気温・湿度 & 温湿度計 & VAISALA 社製(IIMP35D) & 1 基 \\
\hline 風向・風速 & 風向・風速計 & $\begin{array}{l}\text { 小䈉原計器製作所 } \\
\text { 社製 (CW105) }\end{array}$ & 1 基 \\
\hline 日射量 & 日射計 & プリード社製(PCR-02) & 1 基 \\
\hline 入射放射量 & \multirow{2}{*}{ 長短波放射計 } & \multirow{2}{*}{ 英弘精機神製(MR-50) } & \multirow[b]{2}{*}{1 基 } \\
\hline $\begin{array}{l}\text { 反射放射量 } \\
\text { 入射日射量 } \\
\text { 反射日射量 }\end{array}$ & & & \\
\hline 蒸発散量 & 電子天秤 & 新光電子社製 $(C G X-60 \mathrm{~K})$ & 2 台 \\
\hline 表面温度 & T型熱電対 & 福音特殊金禹社製 & 8 点 \\
\hline SAT近隣風速 & 超音波風速計 & $\begin{array}{l}\text { カイジョーソニック社製 } \\
\text { (DA600-3TV) }\end{array}$ & 1 基 \\
\hline
\end{tabular}

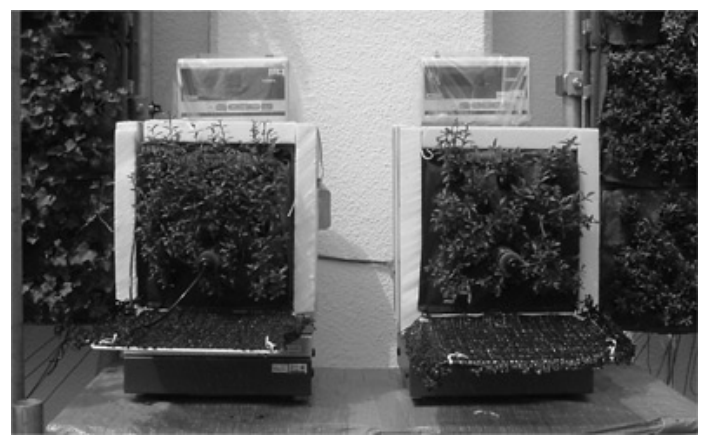

写真－1＼cjkstart電子秤を使用した蒸発散量の計測状況

月にピートモスを素材とするパネルの基盤に 1 ユニット当たり 13 個の苗を定植した後, 屋外圃場にて直射日射による生育傷害を 防ぐため，炎天時に寒冷紗で覆う等調整された環境下で管理した。 植物の被覆厚はいずれも約 8 12cm であった。試験体のユニッ 卜を構成するパネルでの植物の葉面積密度を計測するため, 計測 後に試験体ユニット $30 \mathrm{~cm}$ 四方の葉を全て切除し, 葉面積をスキャ ナーで読み取った。緑化パネル試験体に隣接した場所に, 緑化パ ネルを構成しているユニットと同等のユニット 2 基を重量測定用 として設置した。

緑化パネル試験体および計測機器の設置状況を図-1に, また 電子天科を用いた重量法による計測の状況を写真－1に示す。

\section{(2) 測定機器と計測方法}

測定項目と測定機器について表 -1 に示す。温度・湿度・風向・ 風速・日射量については, 緑化パネル試験体から水平方向に約 3 m離れた地点において, 温湿度計(VAISALA 社製: HMP35D)は 気象庁の地上気象計測方法 ${ }^{14)}$ を参考として地表面から $1.5 \mathrm{~m}$ の地 点に, 風向風速計 (小笠原計器製作所社製: CW105) は緑化パネル の高さを考慮して地表面から $2 \mathrm{~m}$ の地点に, 日射計(プリード社 製: PCR-02)は，地表面からの日射反射量も同時計測するため地
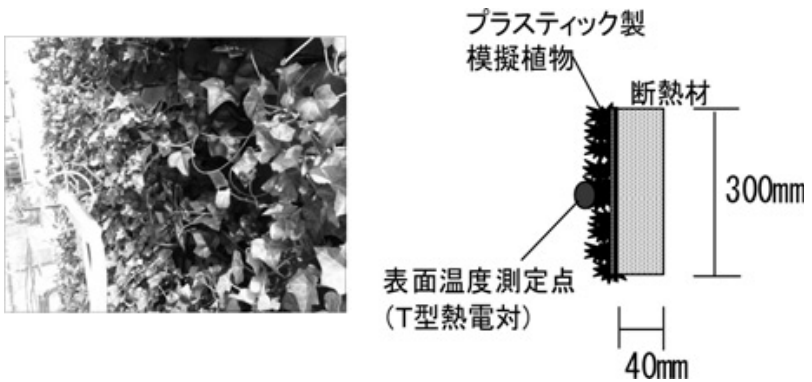

図－2ＳA T計の概要

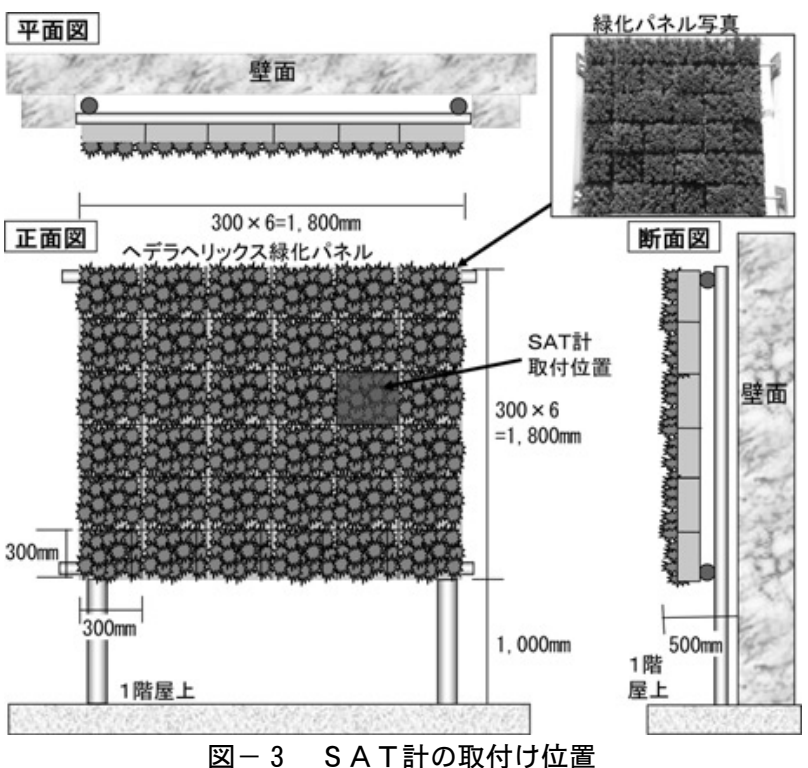

表面から $1 \mathrm{~m}$ の地点に設置した。デー夕出力は 1 分毎に自動計測 を行った。

また，緑化パネル近傍における長波・短波の放射量を計測する ため長短波放射計 (英弘精機社製：MR-50)を試験体の中央部(地 表から約 $2 \mathrm{~m}$ の高さ)に約 $50 \mathrm{~cm}$ 程離して壁面と平行に設置し, デー夕出力は 1 分毎に自動計測した。なお, 設置地点から魚眼レ ンズにて緑化パネル壁面が80\%以上占有していることを確認した。 蒸発散量の計測に当たっては, 重量法により試験体ユニットを 電子天科 (新光電子社製: CGX-60K) に載せて 1 分毎に自動計測 し，減少した重量より蒸発散量を算出した。緑化試験体の環境条 件に近づけるため, 試験体ユニットの周囲を断熱性の良い発泡ス チロールで囲い, 試験体に隣接して設置した。測定は, 終日行い, 蒸発散量は 0:00 から 24:00 までの 24 時間の重量変化量から日蒸 発散量を算出した。

さらに，緑化パネル表面の顕熱フラックスを算出するため，緑 化パネルを模擬した S A T計を製作して計測を行った。 S A T 計 を用いた計測方法については，建材試験センター規格(JSTM) $)^{13)}$ で規定されており, 主として建物外表面対流熱伝達率の測定を目 的として使用されている ${ }^{15)}$ 。ここで，「S A T」とは「Sol-Air T mperature(放射空気温度または相当外気温度)」の略称で,「建 物の周壁近傍の空気の温度に，その壁面に作用する放射の強さを これと等価な空気の温度に換算して加味した温度」と定義され ${ }^{13)}$, 日射と長波放射の授受を考慮して外気温度を補正したものであ る ${ }^{15)}$ 。壁面緑化の実験計測において S A T 計を用いた先行研究と して, 萩島ら ${ }^{9)}$ は, 濃灰色に塗装したスタイロフォームを基盤と して, 模造植物(ブルーパシフィック)を固定した S A T 計を作成 し，対流熱伝達率の測定を行っている。萩島ら ${ }^{9}$ によると，「S A T 計の伝導及び潜熱フラックスをゼロと考えると顕熱フラック 


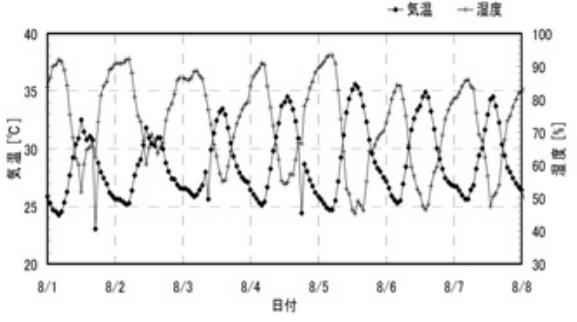

気温・湿度

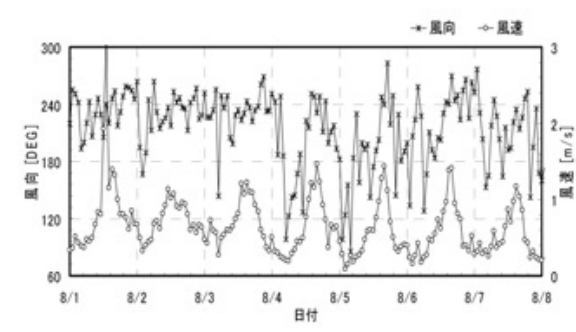

風向・風速

図-4 測定期間中の気象条件 (ヘデラヘリックス)

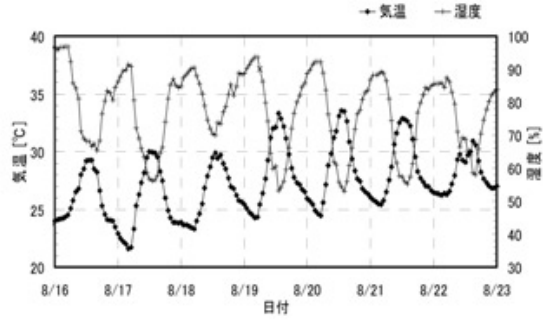

気温・湿度

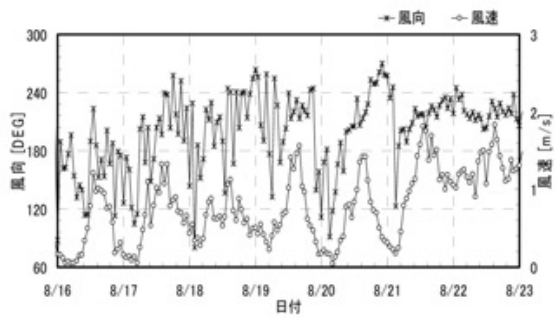

風向・風速

図-5 測定期間中の気象条件 （アメリカツルマサキ）

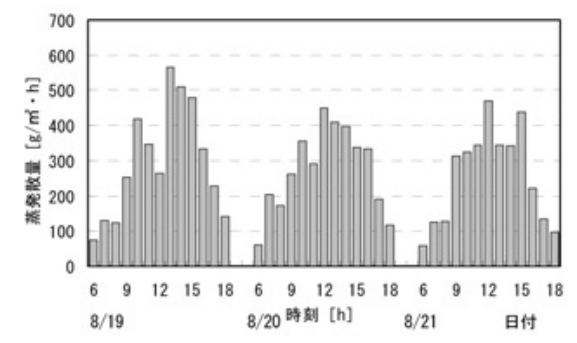

図-6 蒸発散量の経時変化(アメリ カツルマサキ)

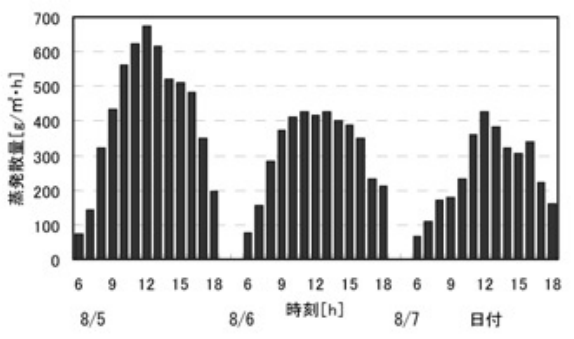

図-7 蒸発散量の経時変化 (ヘデラヘリックス)
スは正味放射量の実測値と等しいとみなせる」として, 長波放射 量の測定值から得られる放射温度と気温の測定值を用いて，S A T計の対流熱伝達率を算出している。本研究では, $\mathrm{JSTM}^{13)}$ の規 格と萩島ら ${ }^{9)}$ の先行研究を参考に, 図 -2 に示すとおり S A T 計 を緑化パネルのユニットと同じサイズとし, 使用植物と類似した 形状のプラスティック製の模擬植物 (市販)を, 緑化パネルとほぼ 同じ葉面積となるように断熱性の基盤材 (スタイロフォーム)に固 定して 全体をつや消し黒色に着色して製作した。また, 図一3 に示すとおり, S A T計は緑化パネルの一部としてパネル試験体 の中に組込んで測定を行った。表面温度を計測するため, パネル 試験体の葉面に 5 点と基材表面に 2 点, S A T 計の葉表面に 1 点 の計 8 点にT型熱電対 (福音特殊金属社製: $\phi 0.2 \mathrm{~mm}$ ) 設置した。

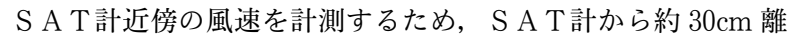
して, 地表面から約 $2 \mathrm{~m}$ の地点に超音波風速計(カイショョーソニッ ク社製社製:DA600-3TV)を設置し，1 分毎に自動計測した。S A $\mathrm{T}$ 計による計測は，ヘデラヘリックスでは 2005 年 8 月 5 日, 6 日 に，アメリカツルマサキについては 8 月 11 日に行った。

\section{（3）測定期間と灌水条件}

緑化パネル試験体の設置は, 2005 年 7 月下旬に行い, 計測機 器の設置を行った後, 気象条件や放射量は 8 月 1 日より計測を開 始した。灌水については, 試験体設置後の降雨状況を考慮しなが ら,計測期間を通じて $3 \sim 4$ 日に 1 回，18 時から 10 分間， $450 \mathrm{ml}$ (降雨に換算して $5 \mathrm{~mm}$ ) 程度行った。

\section{(4) 蒸発効率の算出}

S A T 計による計測值から顕熱フラックスを算出し, (1)式より 刘流熱伝達率を求め ${ }^{16)}$, S A T 計周辺の風速と温度が緑化パネル と同じと見なして, 緑化パネルの対流熱伝達率を S A T計と等し いと見なした。次に, 緑化パネルの対流熱伝達と物質伝達のアナ ロジー(ルイス則)を仮定し, (2)式より物質伝達率を算出し, 重量 法により算出した蒸発散量と, 物質伝達率と飽差との積によって 求まる蒸発量との比から, (3)式より蒸発効率を算出した ${ }^{11), 12)}$ 。

$$
\alpha=\frac{H}{\left(T s_{S A T}-T a\right)}
$$

ここで, $\alpha$ : 対流熱伝達率 $\left[\mathrm{W} / \mathrm{m}^{2} ・ \mathrm{~K}\right], H$ : 顕熱フラックス $\left[\mathrm{W} / \mathrm{m}^{2}\right], T_{S_{S A T}}$ : S A T 計の表面温度 $\left[{ }^{\circ} \mathrm{C}\right], T a$ : 気温 $\left[{ }^{\circ} \mathrm{C}\right]$

$$
\mathrm{kx}=\frac{\alpha}{(\mathrm{Cp} \times \mathrm{Le})}
$$

ここで, $k x$ : 物質伝達率 $\left[\mathrm{kg} / \mathrm{m}^{2} ・ \mathrm{~s}\right], C p$ : 空気の比熱 $[\mathrm{J} / \mathrm{k}$ $\mathrm{g} ・ \mathrm{~K}], L e$ ルイス数(ここでは, 0.83 を用いた。)

$$
\beta=\frac{E}{k x \times\left(e s_{T s}-e a\right)}
$$

ここで, $\beta$ : 蒸発効率, $E$ : 蒸発散量 $\left[\mathrm{kg} / \mathrm{m}^{2}\right], e S_{T s}$ : 表面温度 に対する飽和絶対湿度 $[\mathrm{kg} / \mathrm{kg}], e a$ ：空気の絶対湿度 $[\mathrm{kg} / \mathrm{kg}]$

\section{3. 結果と考察}

本稿では，比較的天候に恵まれた計測日から，ヘデラヘリック スについては 8 月 5 日を中心とする前後 7 日間を, アメリカッル マサキについては 8 月 21 日を中心とする前後 7 日間を対象とし て解析を行った。以下に結果と考察を記す。

\section{(1) 気象概況}

図-4に，ヘデラヘリックスの蒸発散量の実験計測を行った 8 月 1 日から 8 月 7 日までの気象条件として, 気温・相対湿度, 風 向・風速の経時変化を示す。この期間中における最高気温の平均 は $33.9^{\circ} \mathrm{C}$, 最低気温の平均は $24.8^{\circ} \mathrm{C}$ で, 日平均気温は $28.8^{\circ} \mathrm{C} て ゙$ あった。また，相対湿度は 8 月 5 日が最高值 $93.5 \%$ を記録した が, 概ね $90 \%$ から $50 \%$ の間で推移し, 平均湿度は $73.8 \%$ であっ た。風速は午前中に大きくなる傾向が見られ, 最大風速は 8 月 1 日の $3.1 \mathrm{~m} / \mathrm{s}$, 日平均は $0.6 \mathrm{~m} / \mathrm{s}$ であった。

図一 5 に, アメリカツルマサキの蒸発散量の実験計測を行った 8 月 16 日から 8 月 22 日までの気温・相対湿度, 風向・風速の経 時変化を示す。この期間中における最高気温の平均は $31.4^{\circ} \mathrm{C}$, 最低気温の平均は $24.4^{\circ} \mathrm{C}$ で, 日平均気温は $27.3^{\circ} \mathrm{Cであった。ま}$ た，相対湿度は 8 月 16 日が最高 $96.8 \%$ を記録したが，これは前 日の降雨の影響によると考えられる。平均湿度は $77.3 \%$ あっ た。風速は, いずれも午後に大きくなる傾向が見られ，8月21日 と26日の風速が他の計測日に比べて高く, 最大風速が $1.8 \mathrm{~m} / \mathrm{s}$ を 上回った。日平均では $0.8 \mathrm{~m} / \mathrm{s}$ を示し, 風向は南西から南南西が 主流であった。なお，8月16日には $1 \mathrm{~mm}$ の降雨を記録している。

\section{(2) 重量法による蒸散量の計測結果}

蒸発散量は, 使用した緑化パネルの 1 ユニットを電子天秤(新 
表 -2 蒸発散量の計測結果

\begin{tabular}{|c|c|c|c|c|c|}
\hline 区 分 & 項 目 & $8 / 19$ & $8 / 20$ & $8 / 21$ & 平均 \\
\hline \multirow[t]{2}{*}{ 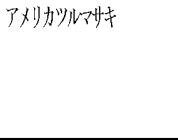 } & $\begin{array}{c}\text { 日蒸発散量 } \\
{\left[\mathrm{g} / \mathrm{m}^{2} \cdot \text { day }\right]}\end{array}$ & 4,308 & 4,015 & 3,833 & 4,052 \\
\hline & $\begin{array}{l}\text { ピーーク時 } \\
{\left[\mathrm{g} / \mathrm{m}^{2} \cdot \mathrm{h}\right]}\end{array}$ & 576 & 457 & 487 & 507 \\
\hline 区 分 & 項 日 & $8 / 5$ & $8 / 6$ & $8 / 7$ & 平均 \\
\hline \multirow[t]{2}{*}{ ヘデランリリタス } & $\begin{array}{c}\text { 日蒸発散量 } \\
{\left[\mathrm{g} / \mathrm{m}^{2} \cdot \text { day }\right]}\end{array}$ & 6,180 & 4,839 & 3,678 & 4,899 \\
\hline & {$\left[\mathrm{g} / \mathrm{m}^{2} \cdot \mathrm{h}\right]$} & 674 & 428 & 428 & 510 \\
\hline \multicolumn{6}{|c|}{ 表-3 対流熱伝達率と物質伝達率 } \\
\hline 区 分 & \multicolumn{2}{|c|}{ アメリカツルマサキ } & \multicolumn{3}{|c|}{ ヘデラヘリックス } \\
\hline $\begin{array}{c}\text { 対流熱伝達率 } \\
{\left[\mathrm{W} / \mathrm{m}^{2} \cdot \mathrm{K}\right]}\end{array}$ & \multicolumn{2}{|c|}{$\alpha_{2}=21.18 \mathrm{u}^{0.44}$} & \multicolumn{3}{|c|}{$\alpha_{1}=23,712 u^{0.6901}$} \\
\hline $\begin{array}{l}\text { 物質伝達率 } \\
{\left[\mathrm{kg} / \mathrm{m}^{2} \cdot \mathrm{s}\right]}\end{array}$ & \multicolumn{2}{|c|}{$K x_{2}=103.12 u^{0.44}$} & \multicolumn{3}{|c|}{$K x_{1}=115.49 u^{0.6923}$} \\
\hline
\end{tabular}

光電子社製：CGX-60K)に載せ, 自動計測により重量変化を 1 分 毎に計測したものを, ユニットからの蒸発散量として算出し, 面 積比から緑化パネル試験体 $1 \mathrm{~m}^{2}$ あたりの蒸発散量として換算した。

灌水は, 計測期間では 8 月 1 日,4 日,17 日,22 日に行った。な お, 重量の測定值については, 風の影響による電子天秤の計測值 のばらつきを平準化するため, 30 分の移動平均を行った。

計測期間中のアメリカツルマサキについては図 -6 に, ヘデラ ヘリックスについては図ー7に示す。計測結果から得られた日蒸 発散量は，表－2 に示すと打りであり，アメリカツルマサキでは 8 月 19 日が最も多く $4,308 \mathrm{~g} / \mathrm{m}^{2}$ となり, 8 月 21 日が $3,833 \mathrm{~g} / \mathrm{m}^{2}$ と 暫減している。3 日間の日中蒸発散量は, 3 日間平均で $4,052 \mathrm{~g} /$ $\mathrm{m}^{2}(4.1 \mathrm{~mm}$ に相当)であった。

一方, ヘデラヘリックスでは 8 月 5 日が最も多く $6,180 \mathrm{~g} / \mathrm{m}^{2}$ と なり, 8 月 6 日が $4,839 \mathrm{~g} / \mathrm{m}^{2}, 8$ 月 7 日が $3,678 \mathrm{~g} / \mathrm{m}^{2}$ と暫減してい る。 8 月 5 日の蒸発散量が大きくなったのは, 前日 8 月 4 日の夕 刻に十分な灌水を行っており, 土㙵含水率が高かったこと, 終日 晴れていて最高気温が $34.2^{\circ} \mathrm{C}$ を記録し，他の計測日よりも日照 時間も長かったこと等が要因と推察される。3 日間の日中蒸発散 量は, 3 日間平均で $4,899 \mathrm{~g} / \mathrm{m}^{2}(4.9 \mathrm{~mm}$ に相当)であった。蒸発散 量が暫減しているのは，計測期間中に灌水を行わなかったため, 土壌中の水分量の減少に伴い, 基材からの蒸発量と植物からの蒸 散量も減少したためと考えられる。

いずれの計測日も気温・日射量の最大ピークとなる 12:00〜 13:00 に最高值を示し, 時間当たりアメリカッルマサキで は 457〜 $576 \mathrm{~g} / \mathrm{m}^{2}$ ，ヘデラヘリックスでは 428〜 $674 \mathrm{~g} / \mathrm{m}^{2} を$ 示した。 なお,重量法の実験計測後に算出したへデラヘリックスの葉面積 指数は 1.45 , アメリカツルマサキの葉面積指数は 1.18 であった。

\section{（3）対流熱伝達率と物質伝達率の算出}

緑化パネル表面に打ける熱収支と放射収支については，萩島 ら ${ }^{9)}$ 壁面緑化における伝熱モデル式を参考として, 熱収支式は (4)式で，放射収支式は(5)式で表すことができる。

熱収支式 : $R n=H+L E+G$

ここで, $R n:$ 正味放射量 $\left[\mathrm{W} / \mathrm{m}^{2}\right], H$ : 顕熱フラックス $\left[\mathrm{W} / \mathrm{m}^{2}\right]$, $L E$ : 潜熱フラックス $\left[\mathrm{W} / \mathrm{m}^{2}\right], G$ : 伝導熱フラックス $\left[\mathrm{W} / \mathrm{m}^{2}\right]$

放射収支式 : $R n=(1-a) S_{i n}+L_{i n}-a ̊ o ́ T S^{4}$

ここで, $a$ : 日射反射率 (アルベド), $S_{\text {in }}$ : 入射日射量(短波放 射量) $\left[\mathrm{W} / \mathrm{m}^{2}\right], L_{i n}$ : 入射放射量 $\left[\mathrm{W} / \mathrm{m}^{2}\right], \varepsilon$ : 放射率, $\sigma$ : ステファン・ボルッマン定数 $\left(=5.670 \times 10^{-8} \mathrm{~W} / \mathrm{m}^{2} \cdot \mathrm{K}^{4}\right), \quad T_{S}$ : パネル表面温度[K]

本研究では, 対象とする緑化パネル壁面に対して, 長短波放射
計を壁面に平行に設置して長波・短波の放射量を計測しており， 同計測器で計測した入射日射量(短波) ( $\left.S_{i n}\right)$ には，太陽からの直 達日射だけでなく, 散乱日射, 地表面で反射した日射量の一部屯 含まれる。また，入射放射量(長波) $\left(L_{i n}\right)$ には，天空からの放射 と大気放射だけでなく，地表面からの放射量も含まれている。

緑化パネル壁面の最下部と最上部では, 地表面と天空部などの 形態係数が異なり，入射放射量が異なる可能性があるが，本計測 では，長短波放射計を対象とする緑化パネル壁面のほぼ中央部に 設置して緑化面への入射放射量も平均化されていると考え，形態 係数による補正は行っていない。

一方，計測前に魚眼レンズにて対象とする緑化壁面を捕捉し， 対象とする緑化パネル試験体が画面の 8 割以上を占め, かつ地表 面からの影響がほとんど見られない設置地点として，地上から約 $2 \mathrm{~m}$,対象緑化壁面から $0.5 \mathrm{~m}$ 離した地点に長短波放射計を設置した。

また，計測前に赤外カメラにて，周辺のコンクリート壁面(白 色塗装) と緑化パネル壁面との表面温度差がほぼ同じであったこ とを確認し，輻射放射量 $\left(L_{\text {out }}\right)$ についても，形態係数による補正 は行わなかった。

なお，地表面からは上向きの放射と顕熱フラックスが生じてい るが，赤外カメラで捕捉した緑化パネルの表面温度分布はほぼ均 一で，高低差が見られなかったため，その影響については考慮し ていない。壁面への地表面からの顕熱フラックスの影響の程度や 地表面からの温度勾配の正確な計測による熱収支メカニズムの解 明については, 今後の課題としたい。

$\mathrm{S}$ A T 計では植物の葉は模擬植物であり，ユニット基材は断熱 材 (スタイロフォーム)で構成しているため, 萩島らの先行研究 ${ }^{9}$ を参考として, S A T計表面からの蒸発と断熱性基材への伝導は 無いと仮定した。また, S A T 計表面をつや消し黒色で着色して いることから，(5)式においてアルベド(a)を 0，放射率 $(\varepsilon)$ を 1.0 と仮定することで, 正味放射量 $(R n)$ は入射日射量 $\left(S_{i n}\right)$ と入射放 射量 $\left(L_{i i n}\right)$ および S A T 計の表面温度から算出される輻射量 $\left(L_{\text {out }}\right)$ により得ることができる。ここで, S A T 計の表面温度 $\left(T_{S S A T}\right)$ は, 熱電対の計測値から算出した。これより, S A T 計表面の顕 熱フラックスは，(6)式から得ることができる。

$$
H=R n=S_{i n}+L_{i n}-o ́ T_{S S A T} T^{4}
$$

得られた顕熱フラックスと S A T 計の表面温度と気温の関係か ら, (1)式により対流熱伝達率 $\left(\alpha\left[\mathrm{W} / \mathrm{m}^{2} ・ \mathrm{~K}\right]\right)$ を算出した。こ こで,対流熱伝達とは, 壁体表面とその近傍空気との温度差があ ることに起因する伝熱現象であり, 対流熱伝達率は, 壁面(個体) と空気(流体)との間の単位時間当たりに壁面から空気へ伝達され る熱の割合を示す。また, 緑化パネル壁面での対流熱伝達率は, 「試験体周辺の風速・温度境界層が, 周囲と大差ないと見なせる 場合 $\left.{ }^{15}\right\rfloor$ と判断して, SAT 計より算出した対流熱伝達率と等しい と見なした。成田ら ${ }^{6), 12)}$ は, 熱伝達と物質伝達のアナロジー(ル イス則)を仮定し，顕熱フラックス $(H)$ と対流熱伝達率 $(\alpha)$ から 物質伝達率 $(k x)$ を算出しており, 本研究においてもこの方法に 従って, 対流熱伝達率 $\left(\alpha\left[\mathrm{W} / \mathrm{m}^{2} \cdot \mathrm{K}\right]\right)$ 加ら物質伝達率 $(k x[\mathrm{k}$ $\left.\left.\mathrm{g} / \mathrm{m}^{2} ・ \mathrm{~s}\right]\right)$ を算出した。ここで, 物質伝達率は単位時間当たり の水分の移動量を表し，(2)式で与えられる。

表面温度と気温の温度差が小さくなる条件では対流熱伝達率の 推定誤差が大きくなるため, 今回の実験においては S A T 計の表 面温度と気温の温度差が $5^{\circ} \mathrm{C}$ 以上となる条件において, 対流熱伝 達率の算出を行った。使用したデー夕は 24 時間を対象として 1 分毎に計測したデータについて 10 分間の移動平均を行い 10 分毎 に整理した。得られた対流熱伝達率と風速との関係について, ア メリカツルマサキについては 8 月 11 日の結果を図 -8 に, ヘデラ ヘリックスについては 8 月 5,6 日の 2 日間の結果を図 -9 に示す。 同じく, 物質伝達率と風速との関係を, それぞれ図 -10 と図一 


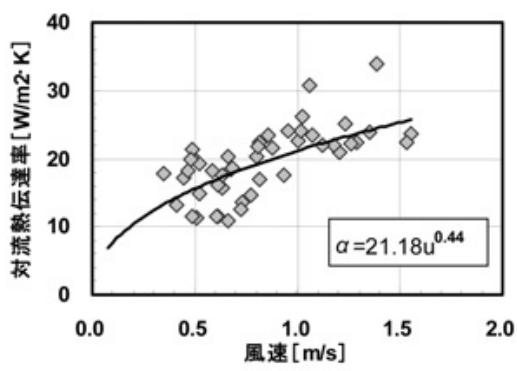

図-8 風速と対流熱伝達率の関係 (8 月 11 日: アメリカツルマサキ)

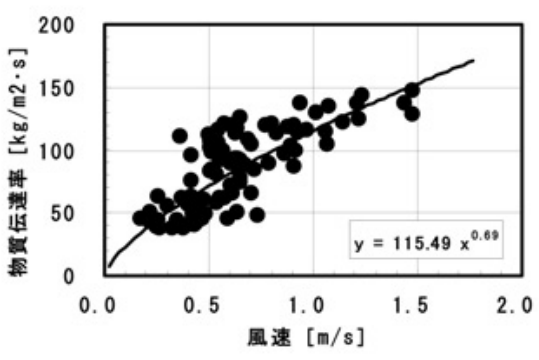

図-11 風速と物質伝達率の関係 (8月 5,6 日:ヘデラヘリックス)

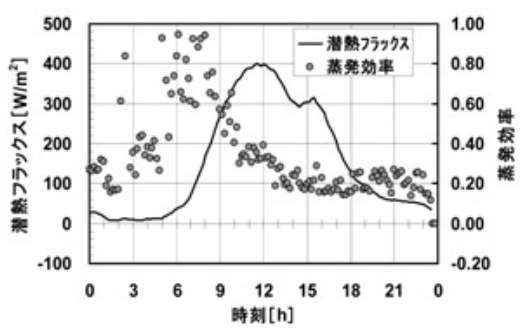

図-14 潜熱フラックスと蒸発効率の 経時変化（8月 5 日:ヘデラヘリックス）

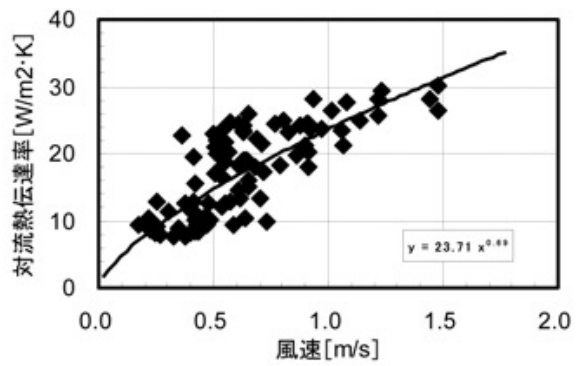

図-9 風速と対流熱伝達率の関係

(8月 5,6 日:ヘデラヘリックス)

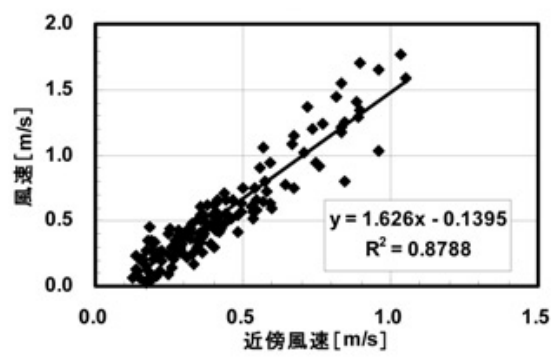

図-12 近傍風速之風速の関係 (8月 5 日)

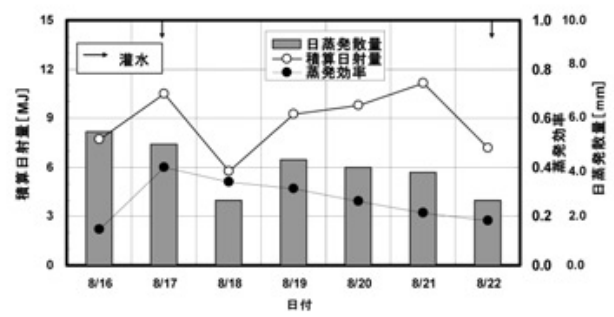

図-15 日積算日射量と日蒸発散量, 蒸発効率(アメリカツルマサキ)

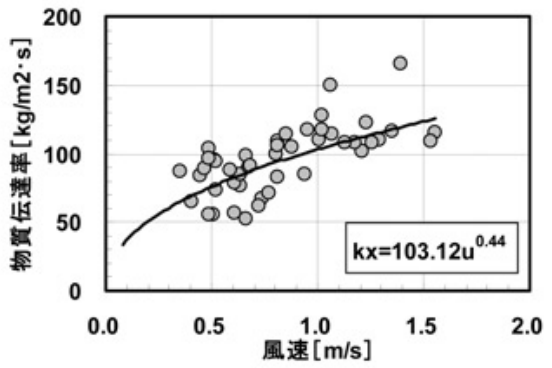

図-10 風速と物質熱伝達率の関係 (8月 11 日:アメリカツルマサキ)

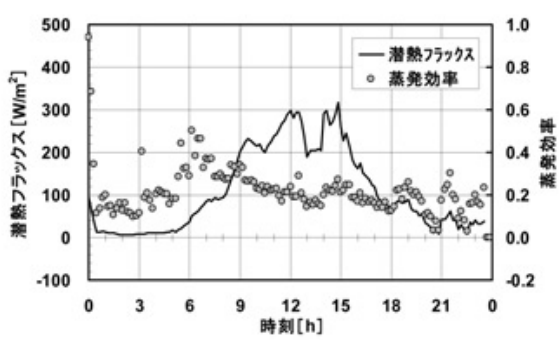

図一13 潜熱フラックスと蒸発効率の経時 変化(8月 21 日:アメリカツルマサキ)

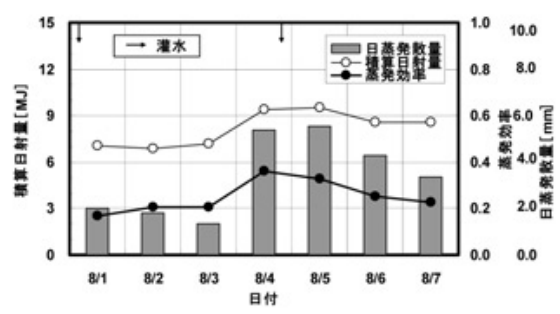

図-16 日積算日射量と日蒸発散量, 蒸効発率(ヘデラヘリックス)
11 に示す。対流熱伝達率と物質伝達率は, 風速と良好な対応関 係が見られたことから，風速の測定值より測定期間中における緑 化パネル面での対流熱伝達率および物質伝達率の算出式を導出し た。

算出結果は, 表一 3 に示すとおりである。なお, S A T計近傍 (約 $30 \mathrm{~cm}$ )の風速值と気象条件として壁面から約 $3 \mathrm{~m}$ 離れ, 地表 面から $2 \mathrm{~m}$ の高度で計測した風速值との相関を見たところ, 図一 12 に示すとおり両者に高い相関が見られたことから, 本研究で は気象条件として計測した風速值を壁面近傍での風速と見なして, 対流熱伝達率を算出した。

\section{（4）蒸発効率による評価}

次に, 緑化パネルの蒸発散特性を評価する指標としての「蒸発 効率 $(\beta) 」$ の算出を試みた。具体的には, (2)式により求めた緑化 パネル試験体の物質伝達率 $(k x)$ にパネル表面の飽和絶対湿度 $(e$ $S_{T S}$ ) と空気の絶対湿度 $(e a)$ との差である「飽差」を乗じることに よって算出した蒸発散量と, 重量法による計測值から得られた蒸 発散量 $(E)$ の測定值との比から, (3)式により蒸発効率 $(\beta)$ の算出 を試みた。蒸発効率 $(\beta)$ は, 蒸発の起こりやすさを表す指標とし て用いられ， 0 から 1 までの数值を示す ${ }^{17)}$ 。葉表面の水蒸気が飽 和状態では 1 を, 乾燥状態で蒸散がない状態では 0 を示す。

蒸散活動が植物の気孔の開閉を通じて行われることから, 蒸散 が盛んとなり, 気孔が開いている状態では, 蒸発効率も高くなる
一方, 気孔が閉じて蒸散活動が少なくなれば，蒸発効率も低い数 值を示すこととなる。近藤 ${ }^{17}$ によると，水田では $0.5 \sim 0.8$, 牧草 地では $0.2 \sim 0.4$ の数值を報告している。

蒸散量による比較はそのときどきの気象要因の影響を受けて変 化するが, 蒸発効率を捕捉することにより, その都度蒸散量を計 測せずに植物種や緑化タイプの違い等による蒸発散特性の把握が 可能になるものと考えられる。

(3)式中の蒸発散量 $(E)$ には, 重量法により計測した表-2に示 す実測值を用いた。ここで, 蒸発散量 $(E)$ は, 植物からの蒸散量 之基材表面からの蒸発量の合計值である。計測した蒸発散量から, (7)式を用いて潜熱フラックス(輸送量)を算出した。

$L E=L \times E$

$L=2.5 \times 106-2400 \times$ èa

ここで, $L E$ : 潜熱輸送量 $\left[\mathrm{W} / \mathrm{m}^{2}\right], L$ : 気化の潜熱 $[\mathrm{J} / \mathrm{kg}]$, $E:$ 蒸発速度 $\left[\mathrm{kg} / \mathrm{m}^{2} \cdot \mathrm{h}\right], \quad \grave{e} a:$ 表面温度 $\left[{ }^{\circ} \mathrm{C}\right]$

アメリカッルマサキについては, 表 -2 の計測日のうち 8 月 21 日における蒸発効率と潜熱フラックスの経時変化を図一 13 に, ヘデラヘリックスについては 8 月 5 日における算出した緑化パネ ルの蒸発効率と潜熱フラックスの経時変化を図 -14 に示す。ア メリカツルマサキでは, 夜間は 0 近傍で推移し, 日の出とともに 上昇して日中は安定し，15時頃から徐々に小さくなる傾向が見ら れる。一方, ヘデラヘリックスでは, 日の出後から 9 時ごろまで 


\begin{tabular}{|c|c|c|}
\hline 区 & 分 & 蒸発効率算出結果 \\
\hline アメリカツルマサキ & & 0.26 \\
\hline ヘデラヘリックス & & 0.25 \\
\hline
\end{tabular}

值の変動が大きく不安定であるが, この時間帯は入射日射量, 気 温, 湿度の気象条件が安定しなかったことが要因と推察される。 その後次第に減少し, 13 時以降には安定した。

これより, 数值の比較的安定していた 9 時から18時までについ て, 緑化パネルの蒸発効率を平均すると, アメリカツルマサキで

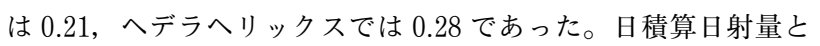
蒸発効率および日蒸発散量の日変化を, アメリカツルマサキは図一 15 に, ヘデラヘリックスは同じく図－16に示した。日蒸発散量 は緑化パネル面積を基準として $1 \mathrm{~m}^{2}$ 当たりに換算した值である。

今回評価を行った緑化パネルのうち, アメリカツルマサキの日 蒸発散量について, 天候が良い日に扔いては $4 \mathrm{~mm}$ 程度であり, 測定期間中の最大值は $5.5 \mathrm{~mm}$ であった。日積算蒸発量は, 日積 算日射量との間で良好な対応関係が見られたが，蒸発効率との間 では顕著な対応関係は見られなかった。蒸発効率は, $0.2 〜 0.4$ の 範囲で変化し, 計測期間での蒸発効率の平均值は 0.26 であった。

一方, ヘデラヘリックスの日蒸発散量は, 天候が良い日において は4 5mm程度であり, 測定期間中の最大值は約 $5.5 \mathrm{~mm}$ でアメリ カツルマサキとほぼ同様の数值を示した。日積算蒸発散量につい ても, 日積算日射量の変化と相似しており, 日積算日射量が多い日 ほど蒸発散量が多くなる傾向が見られた。蒸発効率は, $0.2 \sim 0.4$ の範囲で変化し, 計測期間での蒸発効率の平均值は 0.25 となった。

算出の結果を表 -4 に示す。上述した近藤 ${ }^{17}$ の計測結果による と, 牧草地 $0.2 \sim 0.4$ とほぼ同じ範囲の数值を示しており, 成田 $ら^{6)}$ が新宿御苑で行った計測結果による芝生での蒸発効率 0.4 と 比較すると今回得た壁面緑化パネルでの数值はやや下回っていた。

これは, 芝生面では牧草地よりも草丈が短いことから, 土猿か らの蒸発量が牧草地よりも大きいことが推察される。また, 壁面 緑化では本研究に使用した植物種の違いに加えて, 芝生地が日射 を水平面で受けるのに対して垂直面で受けるため, 大気放射量, 直達日射による放射環境が異なっていること, 生育基盤となる土 壌が薄層であり, 土㙵の含水状態が異なること等の違いが影響し ているものと考えられる。

なお, 萩島ら ${ }^{16)}$ による S A T 計法の短所として「試験体に黒 色塗装を施すことで, 試験体表面が実際の建物外表面に比べ高温 となり, 測定対象面の温度境界層を乱す可能性」を指摘している。

今回の実験計測では, S A T 計を緑化パネル面の一部に設置し たため, 緑化パネルからの蒸発潜熱の影響により, S A T 計単独 で計測した場合よりも表面温度は過小に評価されている可能性が ある。また, 本研究では, S A T 計と緑化パネルの境界層での気 温が同じと見なして, 各々の表面境界層における温度計測は行っ ていないため, 境界層でのより詳細な計測によるデー夕の捕捉が 必要と考えられる。さらに, 今後, 渦相関法等他の方法による顕 熱フラックスの計測值との比較・検討を行う等により, S A T 計 法により得た顕熱フラックスの計測值の検証と計測精度の向上を 図ることが課題である。

\section{4. まとめ}

壁面緑化による温熱環境改善効果を定量的に評価するために, アメリカツルマサキとヘデラヘリックスを植栽した緑化パネル試 験体からの蒸発散に伴う熱収支特性に関する実験・計測を行った。 実験・計測により得られた主な結果は, 以下のとおりである。 1) 対流熱伝達率および物質伝達率については, 緑化壁面近傍での 風速との強い相関が見られ, 風速の関数として導出することがで
きた。

2)蒸発効率は, 計測期間での平均值からアメリカツルマサキでは 0.26, ヘデラヘリックスでは 0.25 を示した。

3) 今回使用した壁面緑化パネルの日蒸発散量は, いずれの植物で も 4 $5 \mathrm{~mm}$ であった。

S A T 計により顕熱フラックスを算出するとともに, 対流熱伝 達率と物質伝達率を得て, 壁面緑化の蒸発散特性を示す数值とし て蒸発散量の実測に基づく蒸発効率を算出することができた。壁 面緑化による温熱環境改善効果として, 植物の蒸発散に伴う潜熱 消費による効果は大きく, 実測值から得られた蒸発効率をパラメー 夕として使用することにより, 壁面緑化の温熱環境改善効果をシ ミュレーション解析する場合等において実証性の高い数值評価が 可能となると考えられる。今後, 植物種や緑化夕イプの違い等に 応じた蒸発効率について, 更なるデー夕の蓄積が望まれる。

\section{謝辞}

本論文のとりまとめに当たっては, 千葉大学園芸学部本條毅教 授よりご指導とご助言をいただいた。また，本研究の実験・計測 に当たって，(独)建築研究所の瀬戸祐直主任研究員にご協力いた だいた。ここに，記して謝意を表します。

\section{引用文献}

1) 関係府省連絡会議：ヒートアイランド対策大綱：環境省ホームページ $<$ http://www.env.go.jp/press $>2004.3 .30$ 参照

2 ) 萩島理・成田健一・谷本潤・三坂育正・松鴆篤・尾之上真弓 (2004): 大規 模な階段状緑化屋根を有する建築物周辺の微気像に関する実測調查： 日本建築学会環境系論文集 $577,47-54$

3 ）三坂育正・石井康一郎・横山仁・山口隆子・成田健一（2005）：軽量・薄 層型屋上緑化技術のヒートアイランド緩和効果の定量評価に関する研 究：日本建築学会技術報告集 $21 ， 195-198$

4 ) 山口隆子・横山仁・石井康一郎（2005）：軽量薄層型屋上緑化システム におけるヒートアイランド緩和効果：ランドスケープ研究 68(5), 509-512

5 ）鈴木弘孝・三坂育正・村野直康・田代順孝（2005）：壁面緑化による 建物外部の温熱環境改善効果に関する研究 : ランドスケープ研究 68 (5), 503-508

6 ）成田健一・三上岳彦・菅原広史・本條毅（2004）：新宿御苑における 蒸発効率と温熱環境の実測：環境情報科学論文集 18,253-258

7 ) 本條毅・菅原広史・三上岳彦・成田健一・桑田直也 (2000)：新宿御 苑のクールアイランド効果の実測：環境情報科学論文集 14, 273-278

8 ）野島義照・長谷川秀三（1995）：夏季における各種造園植物の葉面か らの蒸散量 : ランドスケープ研究 58(5), 97-100

9 ）萩島理・谷本潤・高尾京子（2005）：壁面緑化システムの熱収支構造 に関する屋外観測：日本建築学会技術報告集 N022, 253-258

10）高尾京子・谷本潤・萩島理（2004）：壁面緑化システムの熱収支構造 に関する長期屋外観測：日本建築学会学術講演梗概集, 711-712

11）成田健一・三坂育正・国島武史・中山康隆・若林伸介（2004）：蒸発 効率を用いた保水性舗装の性能評価：日本建築学会技術報告集 No.20, $187-190$

12）成田健一・野々村善民・小笠顕（1997）：自然風下における空面対流 物質伝達率の実測 都市域における建物外表面対流熱伝達率に関する 実験的研究(その 1)：日本建築学会計画系論文集 No.491，49-56

13）建材試験センター規格（2003）：JSTM J 6110 S A T計による建築 周壁の放射空気温度測定方法：<http://www.jtccom.or.jp/hyojyun /jstm.htm>参照

14）気象庁：地域気象観測所一覧: <http://www.data.kishou.go.jp/meta /amedas/ame master.pdf>参照

15）萩島理・谷本潤・成田健一（2004）：都市表面の対流熱伝達率に関す る既往研究のレビュー：水門・水資源学会誌 17(5)，536-554

16）田中俊六・武田仁・足立哲夫 - 土屋喬雄（1985）：最新建築環境工学: 井上書院, 317pp.

17）近藤純正編著（1994）：水環境の気像学-地表面の水収支, 熱収支: 朝 倉書店, $350 \mathrm{pp}$ 